WELFARE MIGRATION:

\title{
IS THE NET FISCAL BURDEN A GOOD MEASURE OF ITS ECONOMIC IMPACT ON THE WELFARE OF THE NATIVE BORN POPULATION?
}

\author{
Assaf Razin \\ Efraim Sadka \\ Working Paper 10682 \\ http://www.nber.org/papers/w10682 \\ NATIONAL BUREAU OF ECONOMIC RESEARCH \\ 1050 Massachusetts Avenue \\ Cambridge, MA 02138 \\ August 2004
}

The views expressed herein are those of the author(s) and not necessarily those of the National Bureau of Economic Research.

(C2004 by Assaf Razin and Efraim Sadka. All rights reserved. Short sections of text, not to exceed two paragraphs, may be quoted without explicit permission provided that full credit, including (C notice, is given to the source. 
Welfare Migration: Is the Net Fiscal Burden a Good Measure of Its Economic Impact on the Welfare of the Native Born Population?

Assaf Razin and Efraim Sadka NBER Working Paper No. 10682

August 2004

JEL No. F2, H3, I2

\section{ABSTRACT}

Migration of young workers (as distinct from retirees), even when driven in by the generosity of the welfare state, slows down the trend of increasing dependency ratio. But, even though low-skill migration improves the dependency ratio, it nevertheless burdens the welfare state. Recent studies by Smith and Edmonston (1977), and Sinn et al (2003) comprehensively estimate the fiscal burden that low-skill migration imposes on the fiscal system. However an important message of this paper is that in an infinite-horizon set-up, one cannot fully grasp the implications of migration for the welfare state, just by looking at the net fiscal burden that migrants impose on the fiscal system. In an infinite-horizon, overlapping generations economy, this net burden, could change to net gain to the native born population.

Assaf Razin

Eitan Berglas School of Economics

Tel Aviv University

Tel Aviv 69978

ISRAEL and NBER

razin@tau.ac.il

Efraim Sadka

Eitan Berglas School of Economics

Tel Aviv University

Tel Aviv 69978

ISRAEL 


\begin{abstract}
Migration of young workers (as distinct from retirees), even when driven in by the generosity of the welfare state, slows down the trend of increasing dependency ratio. But, even though low-skill migration improves the dependency ratio, it nevertheless burdens the welfare state. Recent studies by Smith and Edmonston (1977), and Sinn et al (2003) comprehensively estimate the fiscal burden that low-skill migration imposes on the fiscal system. However an important message of this paper is that in an infinite-horizon set-up, one cannot fully grasp the implications of migration for the welfare state, just by looking at the net fiscal burden that migrants impose on the fiscal system. In an infinite-horizon, overlapping generations economy, this net burden, could change to net gain to the native born population.
\end{abstract}

\title{
2 Introduction
}

Following its recent and forthcoming enlargements, the European Union is likely to face a rise in welfare migration. Hans-Werner Sinn (Financial Times, July 12th, 2004) puts this issue succinctly:

"There will be more migration in Europe, but it will be 'bad' migration as well as 'good'. 'Good' migration is driven by wage and productivity difference.

'Bad' migration is driven by the generosity of the welfare state."

Indeed, we demonstrated elsewhere that the generosity of the welfare state, as by itself, drives out high-skill migration and drives in low-skill migration (see Razin and Sadka (2001, forthcoming)).

Europe, both "old" and "new", faces also a severe aging problem. This shakes the financial soundness of the welfare state, especially its old-age security and medical health components, because there are fewer workers asked to support increasing numbers of re- 
tirees (that is, the dependency ratio rises). ${ }^{1}$ As put metaphorically by the Economist (March 15th, 2003, p.80):..." the fiscal burden on the diminishing number of worker-bees will rise as more people turn into pensioner drones." Note that migration of young workers (as distinct from retirees), even when driven in by the generosity of the welfare state, slows down the trend of increasing dependency ratio. However, intuition suggests that even though lowskill migration improves the dependency ratio, it nevertheless burdens the welfare state. ${ }^{2}$ This is because low-skill migrants are typically net beneficiaries of a generous welfare state. Indeed, in 1997 the U.S. National Research Council sponsored a study on the overall fiscal impact of immigration into the U.S.; see Smith and Edmonston (1997). ${ }^{3}$ The study looks carefully at all layers of government (federal, state, and local), all programs (benefits), and all types of taxes. For each cohort, defined by age of arrival to the U.S., the benefits (cash or in kind) received by migrants over their own lifetimes and the lifetimes of their first-generation descendents were projected. These benefits include Medicare, Medicaid, Supplementary Security Income (SSI), Aid for Families with Dependent Children (AFDC), food stamps, Old Age, Survivors, and Disability Insurance (OASDI), etc. Similarly, taxes paid directly by migrants and the incidence on migrants of other taxes (such as corporate taxes) were also projected for the lifetimes of the migrants and their first-generation descendents. Accordingly, the net fiscal burden was projected and discounted to the present. In this way, the net fiscal burden for each age cohort of migrants was calculated in presentvalue terms. Within each age cohort, these calculations were disaggregated according to three educational levels: Less than high school education, high school education, and more than high school education. The findings suggest that migrants with less than high school

\footnotetext{
${ }^{1}$ In Razin and Sadka (forthcoming) we provide a political-economy analysis of the effect of this aging on the welfare state.

${ }^{2}$ Simon (1984) is one of the first studies that brought out this argument.

${ }^{3}$ Responding to concerns in the U.S. (with foreign-born population of roughly 11.5 percent) about the effect of immigration on the economic prospects of native-born, Congress in 1990 appointed a bipartisan Commission on Immigration Reform to review the nation's policies and laws and to recommend changes. In turn, in 1995 the commission asked the National Research Council to convene a panel of experts to assess the demographic, economic, and fiscal consequences of immigration.
} 
education are typically a net fiscal burden that can reach as high as approximately $\$ 100,000$ in present value, when the migrants' age on arrival is between $20-30$ years. $^{4}$

Similarly, a comprehensive study by the IFO Institute estimated the flows of state benefits to the stock of immigrants in Germany in 1997. Account was taken of taxes, contributions, pensions, welfare benefits as well as all indirect benefits from so-called public goods; see Sinn et al (2001). ${ }^{5}$ The findings suggest, for instance, that a migrant family with three children that came to Germany in 1997 and stays for ten years, receives a net benefit totalling about 120,000 euros.

Indeed, the net fiscal effect of the unskilled migrating generation is usually negative. However, in evaluating benefits of low-skill migration to the current (as well as the future) native-born population, it is important to assess the very long-term effect of this migration on the fiscal system. One has to take into account the infinite horizon of the economy, as distinct from the finite lives of its individuals. When the migrants' descendents gradually integrate into the economy, the current native-born population (both workers and retirees), as well as all future generation, may well gain from low-skill migration.

\section{The Infinite-Horizon Argument}

Consider an overlapping-generations model, where each generation lives for two periods. ${ }^{6}$ In each period a new generation with a continuum of individuals is born. Each individual possesses a one unit of labor-schooling time endowment in the first period, when young. There is a pay-as-you-go (PAYG) pension system, which employs payroll taxes (at a flat rate t) on the working young in order to finance a uniform benefit (b) to the aged.

\footnotetext{
${ }^{4}$ See also Auerbach and Oreopoulos (1999) for a further analysis of these findings. Storesletten (2000) calibrated a general-equilibrium, overlapping generations model to capture the effects of inflows of workingage immigrants to the U.S. on the fiscal system, taking into account changes in factor prices.

${ }^{5}$ The findings are also summarized in Table 1 of Sinn (forthcoming). Obviously, pure public goods, such as defense, are not included in the calculations, because immigrants consumption of the services of these goods do not reduce consumption of native born.

${ }^{6}$ We sketch here only the backbones of the analytical framework behind the infinite-horizon argument. A detailed derivation of equations (1)-(4) is contained in Razin and Sadka (1999).
} 
There are two levels of labor productivity: an unskilled worker with low productivity and a skilled worker with high productivity. A skilled worker provides an effective labor supply of one unit, per units of time at work; while an unskilled worker provides only $\mathrm{q}<1$ units of effective labor supply, per units of time at work. The wage per effective units of labor is denoted by w.

Born unskilled, each individual can nevertheless acquire skills, and become a skilled worker, by investing e units of time in schooling, in the first period. The remainder of her time, 1-e, is spent at work as a skilled worker. The individual-specific parameter e reflects the innate ability of an individual in acquiring a work skill. The lower is e, that is the less time she needs to acquire the skill, the more able is the individual. The parameter e ranges between 0 and 1, with a cumulative distribution function, $G(e)$, describing the heterogeneity of the population concerning the cost-of-acquiring-skill parameter e.

In the first period of her life the individual brings $1+\mathrm{n}$ children, decides whether to acquire skill, works, consumes, and saves for retirement in the second period. In the second period she only consumes her retirement saving and pension.

One can show that all individuals with cost-of-education parameter below $\mathrm{e}^{*}=1$-q will acquire skill, whereas all the rest will remain unskilled.

Suppose that at some period (say, period zero), a one-shot wave of $m$ unskilled, working age, migrants are allowed in. They grow up at the same rate (n) as the native-born population, and the ability index of the offspring, who have access to the same education system as the native born is distributed similarly according to the same cumulative distribution function G. That is, the second generation of the immigrant wave are fully integrated into the society. In fact this assumption, together with the infinite horizon of the economy and the PAYG nature of the pension system, are the driving forces behind our argument.

Consider now the following thought experiment. Suppose that the government continues to maintain the pre-migration social security contribution rate, $t$, intact. We then ask what pension benefit can be paid to retirees in our PAYG system. One can show that 
the pension that will be paid to the old, living when the wave of unskilled, working age migration takes place (i.e., period 0), is:

$$
b_{0}=(1+n) t w\left\{\int_{0}^{e *}(1-e) d G(e)+q[1-G(e *)+m]\right\},
$$

whereas the pension paid to all future generations is:

$b_{1}=b_{2}=b_{3}=\ldots=(1+n) t w\left\{\int_{0}^{e *}(1-e) d G(e)+q[1-G(e *)]\right\}$.

Upon inspection of equation (1), one can observe that $b_{0}$, the pension benefit to retirees at the period when the migrants wave takes place, increases in the number of unskilled, working age, migrants. Therefore, as expected, the old generation in period 0 is clearly better-off with migration. Upon inspection of equation (2), one can observe that $b_{1}=b_{2}=$ $b_{3}=\ldots$, the pension benefit to retirees in all post-migration periods, are unaffected by the migration. In particular, and somewhat surprising, the young generation at the time in which unskilled, working age migration takes place (both the skilled and the unskilled native-born members) is not adversely affected by the migration. Thus, the existing nativeborn population will welcome the unskilled, working age migration.

Furthermore, by creating some surplus in the pension system (to be invested in a social security fund) during the period of migration (that is, by lowering $b_{0}$ towards, but not all the way, to the pre-migration pension benefit) the gains that accrue only to the current old, could be spread out to the current young as well as to all future generations. In other words, unskilled, working age migration is a Pareto-improving change with respect to migrants, as well as the existing current and future native born generations.

Strikingly, this result obtains even though the unskilled migrants may well be net beneficiaries of the redistributive pension system, in the sense that the present value of their pension benefits exceeds their pension contributions. To demonstrate this point, we calculate the present value of life-time net fiscal burden (NFB) of a representative unskilled migrant. This burden is: 


$$
\mathrm{NFB}=\frac{1+n}{1+r} t w\left\{\int_{0}^{e *}(1-e) d G(e)+q[1-G(e *)]\right\}-t q w .
$$

One can see that the burden is positive if:

$$
\frac{G(e *)(e *-\bar{e})}{1-e *}>\frac{r-n}{1+n},
$$

where $\bar{e}$ is the skilled population mean of the cost-of-education parameter. Note that $e *>\bar{e}$, because $\mathrm{e}^{*}$ is the upper bound of the cost-of-education parameter of skilled individuals, whereas $\bar{e}$ is the corresponding mean. Thus, the left-hand side of (4) is definitely positive. Consider the plausible case where $r>n$, in which the economy is dynamically efficient. ${ }^{7}$ If a large share of the native-born population is skilled, then condition (4) could be satisfied. In this case, NFB is positive at the same time that unskilled, working age migration is a Pareto-improving change for the migrants and the native-born populations.

As expected (if the host country has a large number of skilled people), then when unskilled, working age migrants come to a country whose pension system redistributes income from the (skilled) rich to the (unskilled) poor, they impose a net fiscal burden. But what we have established is that even though migrants are net "consumers" of the pension system, all existing and future generations of the native-born population may gain from migration .

\section{Conclusion}

An important lesson that we draw here is that in an infinite-horizon set-up, one cannot fully grasp the implications of migration for the welfare state just by looking at the net fiscal burden that migrants impose on the fiscal system. The studies by Sinn et al (2003), and Smith and Edmonston (1977), among others, properly emphasize the fiscal burden that low-skill migration imposes on the fiscal system. However, in an infinite-horizon, overlapping generations economy, this net burden is perfectly consistent with a net gain to

\footnotetext{
${ }^{7}$ Evidently,our argument holds trivially in the implausible case where $\mathrm{r}<\mathrm{n}$ and the economy is inefficient.
} 
the native born population. The additional obligation of the fiscal system to pay pension benefits to the incoming migrants, when they retire, could be shifted forward, in effect, indefinitely. If, hypothetically, the world would come to a stop at a certain point of time in the future, the young generation at that point would bear the deferred cost of the present migration. But in an ever-lasting economy, the migrants, by supplying work and helping the financing the pension benefit of period zero to native born retirees, are a boon to the the host country population: old, young, and future generations. ${ }^{8}$

\section{$5 \quad$ References}

\section{References}

[1] Auerbach, Alan and Philip Oreopoulos, 1999. "Analyzing the Fiscal Impact of U.S. Immigration," American Economic Review, Papers and Proceedings, 89 (May), 176-80.

[2] Razin, Assaf and Efraim Sadka, 1993. The Economy of Modern Israel: Malaise and Promise, University of Chicago Press.

[3] Razin, Assaf and Efraim Sadka, 1995. "Resisting Migration: Wage Rigidity and Income Distribution," American Economic Review, Papers and Proceedings, 85 (May), 312-316.

[4] Razin, Assaf and Efraim Sadka, 1999. "Migration and Pension with International Capital Mobility," Journal of Public Economics, 74, 141-150.

\footnotetext{
${ }^{8}$ Migration may have some other important implications that are not addressed here. Migration may exert a downward pressure on wages. If wages are rigid, then this may cause a rise in unemployment; see Sinn (forthcoming) and Razin and Sadka (1995). But if labor markets are flexible, the pressure may drive wages down; see storesletten (2000) and Razin and Sadka (2000). However, the decline in wages may well be just a short-term phenomena, as it triggers accummulation of new capital; through both domestic savings and international capital inflows. Indeed, the massive immigration into Israel from the former Soviet Union, following the collapse of communism, was met by a fairly flexible labor market, and a massive influx of capital; see Razin and Sadka (1993) for an early account.
} 
[5] Razin, Assaf and Efraim Sadka, 2000. "Unskilled Migration: A Burden or a Boon for the Welfare State," Scandinavian Journal of Economics, Vol. 1 (May), 463-479

[6] Razin, Assaf and Efraim Sadka, 2001. Labor, Capital, and Finance: International Flows, Cambridge University Press.

[7] Razin, Assaf and Efraim Sadka, with the collaboration of Chang Woon Nam, forthcoming. The Decline of the Welfare State: Demography and Globalization, CESifo Monograph Series, MIT Press.

[8] Simon, Julian L., 1984. "Immigrants, Taxes, and Welfare in the United States," Population and Development Review, 10 (March), 55-69.

[9] Sinn, Hans-Werner, forthcoming. "EU Enlargement, Migration and the New Constitution." CESifo Economic Studies.

[10] Sinn, Hans-Werner, Gebhard Flaig, Martin Werding, Sonja Munz, Nicola Dull, Herbert Hofmann, 2001. " "EU Enlargement and Labour Mobility - Consequences for Labour Markets and Redistribution by the State in Germany," CESifo Research Report, November, No. 2.

[11] Storesletten, Kjetil, 2000. "Sustaining Fiscal Policy Through Immigration," Journal of Political Economy, Vol. 108 (2), 300-323. 